\title{
The Analysis of Employee Performance at Semarang Religious Training Center
}

\author{
Rukhana Fitriati \\ Public Administration Departmen, Faculty of Social and olitical Sciences, Diponegoro University
}

\begin{abstract}
Employees play a significant factor for the success of an organization in any organization. Therefore, it is necessary to achieve good performance of employees in a company. Performance is a completion of official tasks and duties to achieve organizational goals. This study analyzed the performance of employees at Semarang Religious Education and Training Center and which aimed to find a solution on how to improve the performance of employees at Semarang Religious Education and Training Center. The research method used was qualitative with qualitative descriptive approach. The results showed that work performance, skills, behavior, abilities and motivation aspects were still not good enough. Moreover, the solution to improve employee performance are such as adding the quantity of employees to help older employees to work, work placement must be based on their educational background, employees' initiatives need to be always encouraged, and holding some programmed team work improvement activities. In addition, it is necessary to conduct special training programs to increase the ability of employees in their own workfields to improve the employees' skills and a motivation training program to increase employees' motivation.
\end{abstract}

\section{Keywords:}

employee; performance; performance analysis

\section{Introduction}

Human resources in organizational activities play a significant role as a one of the most important driving forces for the success of an organization. In addition, human resources are one of the important factors that must be properly considered by all relevant institutions in order to achieve the organizational goal. Besides human resource factors, other factors must also be well concerned as all the factors are eventually related to one another so that they become an integrated unity.

Humans as the organizational driver in nowadays era are highly required by the organization. Almost all organizational output depends on the initiative and work of human resources. Accordingly, almost every problem regarding human resources as the apparatus is 
seen as one determining factor for the success of any program. Therefore, an effectively and efficiently managed organization is highly determined by human resources.

Although an organization owns high quality capital or materials, it will certainly be difficult to achieve the goals of the organization there is no human intervention within the running of the organization. Therefore, the development and empowerment of human resources should be directive and optimally implemented.

Human resources are accordingly an important factor which must be well considered by all institutions and agencies in order to achieve the goals. Effective human resource management is directly related to the success of improving the performance of human resources both at individual level, work group level and organizational level. The success of management in an organization is considerably determined by the human resources working in the organization. This means that humans have the resources and capabilities which fit the demands of the needs in every organizational activities implementation. Accordingly, the expected performance can be achieved.

In governmental institutions, good employee performance is significantly expected. Employee can be defined as an individual who works for an employer either as a permanent or temporary/freelance employee based on a written or unwritten work agreement to carry out a job in a certain position or activity (Mardiasmo, 2011). As the time rapidly changes, critical attitude of the public community towards the demands of employee performance increases significantly, particularly on employees working in public organizations or governmental agencies. This definitely makes an impact that an employee is required to improve his performance, especially the performance of those working in public sector.

Work performance or popularly known as performance is quality and quantity of work achieved by an employee in carrying out his task and duties based on the responsibilities assigned to him (Mangkunegara, 2001). Based on the results of the employee performance survey, specifically on the performance of state civil apparatus (SCA, local term Aparatur Sipil Negara-ASN) or civil servants, there were only $40 \%$ of SCA possess certain skills and expertise at work while the remaining $60 \%$ are in administrative skills. The data were recorded through a survey conducted by the Ministry of State Apparatus Empowerment and Bureaucratic Reforms (local term: KemenPAN RB) (Source: www.jpnn.com). 
From the survey data shows that the performance of employees, especially civil servants is low, this phenomenon also occurs at the Semarang Education and Training Center. In the decree of the head of the center it is stated that the completion of the training result report must be completed 7 days after the activity in fact the employee completes it within 20 days, this indicates that the time to complete the task is not in accordance with the set standard time. Thus it can be concluded that the performance of Semarang Religious Education and Training Center employees in completing tasks is still not in accordance with the established performance indicators. Work performance indicators are quantitative and qualitative measures which describe the level of achievement of a predetermined target or goal (Mahmudi, 2013: 103).

The problem which may cause low work performance is such as the presence of employees in the workplace, leaving the workplace in the middle of working hours without any permission, etc. This shows a low level of discipline which consequently affects employee performance.

Low employee performance is also influenced by unsuitable employees' placement which is not based on their educational backgrounds. According to Saydam (2005: 222), employees' placement must carefully consider the educational background, physical and mental health, work experience, and age of the human resources. Moreover, employees' placement at Semarang Religious Education and Training Center is not fit with the employees' educational background, for example the educational background in financial department should be a bachelor of economics, but the one placed is with a bachelor of education. Thus, the employee doesn't fit with the position required in the finance department. In addition, in technical education section, the personnel placed there is the one with an economics degree which definitely doesn't fit with the main expected duties and functions in which those whose bachelor degree in education should be placed in this technical personnel section. The personnel placed in technical section for making report of education and training results is high school education graduate. This educational background is actually inappropriate enough to be reporting section which commonly requires a minimum bachelor degree background. Based on those problems described, this study will discuss why the performance of Semarang Religious Education and Training Center employees is fairly poor and also will 
identify how to improve the performance of Semarang Religious Education and Training Center employees.

\section{Methods}

The method used in this study is a qualitative research method with a qualitative descriptive approach. The reason why the researcher used qualitative research method is because the researcher tried to describe the existing problems related to the performance analysis of the employees at Semarang religious education and training center. The phenomenon of this research is to analyze the performance of employees while focusing on big questions, i.e. first, why the performance of Semarang religious education and training center employees is not good and second, what is the solution to improve the employees' performance.

The causes of poor employees' performance as the phenomena of the observation in this research were seen from Sedarmayanti framework covering work performance, expertise, behavior. In addition, the phenomena of observing the causes of such poor employees' performance are ability and motivation. The data sources in this research used primary and secondary data. Moreover, to select informants, the researcher used purposive sampling technique. Purposive sampling is the determination of informants based on research needs. (Purwanto et.al, 2007: 47). Furthermore, data collection techniques were carried out by literature studies, interviews, observation, and documentation methods

Data analysis was done by data analysis model from Miles Huberman who argues that analysis activities in qualitative data are carried out interactively which are continuously conducted until it has completely finished and the data become saturated. In addition, data processing includes data reduction, data presentation, and drawing conclusion.

\section{Results and Discussion}

Religious Education and Training Center of Semarang is one institution under the Ministry of Religious Affairs whose main task and function to organize education and training for religious affairs and educational technical personnel, to coordinate and develop partnerships with work organization units within the Ministry of Religious affairs and Local Government (City or Regency) and other educational and training institutions. In addition, 
Religious Education and Training Center is a strategic institution. Based on its duties and functions, it is expected to contribute in improving the quality of Human Resources (HR). Therefore, the employees in this institution are required to improve their performance. However, in fact, the performance of employees in this institution is not satisfactorily enough and needs to be well improved.

\section{The Reasons why the performance of employees at Semarang Religious Education and Training Center is poor}

Work Achievement

Work performance can be assessed by observing various dimensions, i.e. work quality, work quantity, engagement with expertise in planning efforts to work and achievement thoroughly (Wijono, 2010: 78). Work performance is defined as the works achieved by an employee in carrying out his/her duties according to the given responsibilities in terms of work quality. Good or bad performance of an employee will greatly affect the employee's work quality and/or quantity. Thus, if the quality of the employee is poor, it can be stated that his/her performance as an employee is also bad. Work performance in this study is seen from two aspects, the first aspect is running office operational standards at work. From the results of the research, all the employees do the work always based on standard operating procedures which have been established. Based on the observation, it shows that all employees have their own operational standards so that their works do not deviate from the main duties and functions specified. Accordingly, this implies that employees at Semarang Religious Education and Training Center have worked based on predetermined standards. However, seen from aspect of accuracy in the completion of office work, the results of the research showed that many employees work overtime to complete their incomplete work and a lot of work is pending for completion because they were unable to complete the work on time. Thus, they worked overtime to complete the work. In general, from the research observation on how the employees worked, it showed that their works were not conforming to the time which had been predetermined. They mostly think that to get the work done was the most important thing without having to complete it by its predetermined time. This time inaccuracy has led to a lot of work was completed late and eventually make the employees' performance not optimal.

Expertise 
Expertise is the level of technical ability owned by the employee in carrying out tasks and duties assigned to them. The abilities can be in the form of knowledge, initiative, communication and teamwork. This study analyzed expertise from the following aspects: Having knowledge on main duties and functions at work

Knowledge is the most fundamental thing which can be easily observed from a person's expertise. How well the employee has the knowledge and understands his/her duties at work. Basically educational background greatly affects the employee's expertise, on how well the employee possess the knowledge about his/her duties and functions. Knowledge is often linked to educational backgrounds. Employees with suitable backgrounds will certainly master their work. However, the placement of employees at Semarang Religious Education and Training Center is not based on the educational backgrounds. Thus, the employees are not fit with their main duties and functions. This should be seriously concerned so that the placement of employees in the future must be based on the educational background regarding the tasks to be handled. This is important due to the fact that employees whose educational background related with their main duties and functions will certainly bring a significant effect on the results of the work.

Having the initiative to immediately and completely do the tasks and duties

Employees whose self-initiative to work will certainly obtain a good assessment from their leader. Initiative in this case means to immediately complete their work or reports before being asked. Employees who do not have work initiatives can definitely affect employees' performance. Moreover, their main tasks and functions should be carried out more quickly without postponing other tasks. Another initiative is to help colleagues in their work when they have more workload. Employees who do not own any initiative can also be influenced due to their inadequate educational background since a good educational background will produce good output from cooperation aspect in completing their work. Lack of solidity at workplace amongst the employees should be importantly concerned for them to work well cooperatively in completing their duties and tasks. Accordingly, the work can be quickly completed and they can produce good work results based on the work instructions and demands. 
Conducting two-way communication among employees in completing their duties and functions.

Communication is a significant factor to improve employees' performance. A good communication among employees needs to be well established to achieve organizational goals. The results of the research found that two-way communication among employees was not well established. Moreover, intense communication was established only among particularly similar employees. In other words, it seemed that the employees tended to form friends-groups which make them to be more familiar with their own group than with other employees. The research results implied that a two-way communication has not been well established. Meanwhile, with a good two-way communication among the employees, the goals of organizational performance can be more easily achieved.

Creating cooperative collaboration in completing office work

Cooperation is an important factor as an effort to achieve organizational goals. The results of this research showed that there was not any solid cooperation. This could be seen by the absence of reciprocal assistance in carrying out their main tasks and functions in their section. This was probably due to the lack of employees' awareness in working together. Employees mostly only cared about their own work regardless other employees'. This should be well concerned as employees would be able to work together in completing their work to make it completed quickly and eventually to produce good work based on their work objectives which have been previously determined.

Behavior

The performance achieved by an organization or institution is basically the achievement of the members of the organization from the superiors to the subordinate members. Human resources are a vital asset in all organizations. Therefore, some efforts to improve organizational performance are unlikely to succeed if the behavior of the employees is not properly directed. Behavior can be defined as the attitude and manner of the employees which are inherent in them and unconsciously carried out when they are conducting their duties. By possessing good behavior, the goals of the organization can be achieved. There are two aspects of behavior observed in this research as follow:

Conducting disciplinary acts in obeying the office rule

Discipline is a mental attitude and self-control owned by a person or group which is reflected in the acts or behavior in the form of obedience to the rules or regulation set by an 
organization or institution. Discipline is a factor to measure the good or bad performance of any institution. If the employees are not disciplined, how can they perform well? Thus, based on the observation, employees come early in the morning for morning or arrival presence system, but they are not at work and come back at office after afternoon or second presence hour system. This employees' undisciplined act was due to no reward and punishment applied. This should be a serious concern so that employees can improve their discipline properly in working. Consequently, they can increase the performance and professionalism of the employees.

Being responsible for completing work

Responsibility plays an important role in employees' performance because employees who are truly responsible for their duties and work will pay attention to their performance as employees. Based on the results of this study, employees do not have adequate attitude and responsibility for completing their work because of the lack of awareness on the tasks assigned to them. This should be well considered so that employees can decently increase their responsibilities at work. Responsibility attitude is very important at work because without employees' responsibility, the work will not be carried out properly.

Ability

Based on the study, it was found that employees' ability is seen from three aspects as follow:

Complete daily work properly, quickly and on time

The study results showed that many employees make a lot of mistakes in completing daily work. Besides, they work slowly and not on time. Moreover, there are a lot of works in the office which result in less than it was expected. Thus, it leads to poor performance.

Do the duties and functions skillfully

Employees' skills at work were not actually qualified enough to carry out the work activities. This happened because there is a lack of training programs to improve their skills. Accordingly, it is necessary to conduct training for employees based on their duties and functions.

Perform innovative actions to solve problems at work

The results of the study showed that there were still many employees who were not being innovative in solving problems at work. It might be due to the fact that the employees 
were afraid to provide input and/or suggestion when there are any problems arising in the office. They were afraid if their input or suggestion would not be accepted by the leader/senior or by their co-workers, so they preferred to say nothing.

\section{Motivation}

The same thing in addition to poor abilities is also seen from employees' motivation at work. This can be concluded from three sub-aspects as follow:

Having responsibility to do main duties and functions

The study results showed that the employees do not yet have sufficient responsibility to do their own main duties and functions. This may be because the workloads of employees are different, some are small and some are even excessive. Accordingly, there were so many employees put the other duties aside due to the lack of time and because of the uneven work volume for each employee. Employees whose less work volume should be given more volume to make all employees obtain a balanced work load

Dare to take any risk to complete the duties at work

The results of the study showed that employees did not dare to take the risks for solving work problems. This occurred because they were afraid of being blamed by the leader or senior whenever a problem occurs. Consequently, employees do not have the courage to take risks, especially for a hard work.

Being enthusiastic at work

The results of the research showed that the employees' passion and/or spirit to work were really poor. This probably was because besides doing monotonous works, it was related to additional income. The employees who did additional works have not obtained their additional bonus or salary. This made them less enthusiastic to work.

\section{Solution to Improve the performance of Employees at Semarang Religious Educational and Training Center}

By observing the problems which existed as seen in the results of the research, it is necessary to propose some solutions to improve the performance of the employees at Semarang Religious Education and Training Center. Therefore, it can increase the organizational performance which eventually will achieve the goals of the institution 
effectively and efficiently. The followings are some solutions for the problems found in this research seen from some aspects.

a.Work performance

Do standard operating procedures to conduct office work.

There is not any solution suggested for this aspect because all the employees have already implemented standard operating procedures which have been established by Religious Education and Training Center of Semarang.

Punctuality in completing office work

In this sub-aspect, the completion of office work was mostly late. The solution given to this problem is by adding additional employees to help old employees at work, because the workload volume at Semarang Religious Education and Training Center was considerably abundant In addition, it is necessary to equally distribute the works, duties and functions to each employee. Consequently, each employee's work can be completed on time.

b. Expertise

Possess the knowledge about their main duties and functions at work.

In this sub-aspect, the employees' knowledge about their main duties and functions in working was commonly poor. This possibly was due to the fact that the employees' placement was not on educational basis. Consequently, many employees work in the field they are not really skillful at.

The solution proposed is it is necessary to regularly and gradually give training programs for employees to increase their knowledge to work at their section because so far based on the result of the study, this program is still rarely held.

Have the initiative to complete work without waiting for instructions from the leader/senior. In this aspect, the employees did not seem to have the initiative to complete office work. This was because the lack of employees' awareness. The proposed solution is to directly escalate a sense of enthusiasm for employees so that they can be aware of and develop their initiatives at work without having to wait the instructions from their leaders.

Make a two-way communication among employees in completing office work.

In this sub, the communication carried out by the employees in completing office work was commonly not in two-way. This was because of the lack of communication among 
employees. The researcher suggests that it is the roles of the leader who must encourage the employees to build effective communicate at work.

Do cooperative collaboration in completing office work.

In this sub-aspect, the employees seemed not to have solid cooperation. Employees often behaved neglectfully to others and prioritized their work individually without willing to create any cooperative collaboration with other employees. Thus, it is necessary to create some routine teamwork improvement activities at least once a month to build more solid and integrated team which eventually will bring them to be able to do cooperation at work. Behavior

Do disciplinary activities in obeying office rules. In this aspect, the employees seemed not to be disciplined particularly to obey office rules. This might due to no reward and punishment for employees who were disciplined or undisciplined. Thus, the researcher suggests a solution to give strict punishment to employees so they don't do any undisciplined act and become more responsible for their work and providing rewards for employees who are disciplined. Applying rewards and punishments procedures will bring a significant impact on the increasing employees' performance.

Possess responsibility for completing their work on schedule

In this aspect, employees did not have responsibility for completely finishing the work. This was perhaps due to the lack of employees' awareness on their job responsibilities. Accordingly, the solution proposed it is necessary to create an institutional target to complete the work on time

\section{d. Ability}

Complete daily work properly, quickly and on time.

In this sub-aspect, many employees make a lot of mistakes in completing daily work. Besides, their work performance tended to be slow and not on time. The solution proposed is to hold a routine training program according to their work fields so that they can work with their own style.

Do the duties and functions skillfully 
In this sub-aspect, employees' skills at work were not actually competent enough to carry out the work because the lack of training programs to improve their skills. Accordingly, it is necessary to routinely conduct training for employees to improve their soft skill. Perform innovative actions to solve problems at work

At this sub-aspect, the absence of innovation done by the employees to solve the problems at work was due to the lack of encouragement from the leader to the employees to be innovative. As a consequence, the employees tended to do nothing when there were any problems arising in the office. Accordingly, it is necessary to hold training program on problem solving more frequently and to give more encouragement and/or inspiration to employees so that they can be have more skills in innovating to solve problems at work.

\section{Motivation}

Have responsibility to do main duties and functions

In this aspect, the employees seemed not to have sufficient responsibility yet to do their own main duties and functions. This might be because the workloads of employees were different, some were small and some were even excessive. Accordingly, there were employees who did nothing but there were also employees who were overloaded with the works. This would bring some effect on the work result, such as imperfect output. Accordingly, it is suggested for the leader to equally distribute the workload to all employees. Each employee is calculated his/her workload based on their main duties and functions. If it can be done, the workload volume for all employees will be evenly distributed and this will make the employees feel if their workload is not too hard put the other duties aside due to the lack of time and because of the uneven work volume for each employee. Consequently, each personal employee responsibility will increase.

Dare to take risks in solving Dare to take any risk to complete the duties at work

In this sub-aspect, the employees did not dare to take the risks for solving work problems. This occurred because the lack of encouragement and motivation from the leader and they were afraid of taking a risk in completing their work. Thus, it is suggested to hold team building activity at least every month to give more courage and motivation for the employees so that they can have more bravery to take risks in completing their work.

Being enthusiastic at work 
The lack of employees' passion and/or spirit to work was because besides doing monotonous works, it was related to additional income. The employees who did additional works have not obtained their additional bonus or salary. This made them less enthusiastic to work. Accordingly, it is necessary to hold planned motivational training to increase employees' motivation and also to provide additional income or bonus which is given on time that will make the employees more enthusiastic to work.

\section{Conclusion}

This study focusing on work performance of the employees at Semarang Religious Education and Training Center concluded:

The causes of the poor performance of Semarang Religious Education and Training Center employees seen from Sedarmayati theoretical framework are i.e. work performance aspect, the employees were not on time in carrying out office operational standards at work and in completing office work; expertise aspect, employees' knowledge on their main tasks and functions was not adequate, employees did not have high initiative at work, employees' communication was not in two-way direction and employees' cooperation was not solid yet; and behavior aspect, many employees were not disciplined and did not have responsibility for work

The causes of the poor performance of Semarang Religious Education and Training Center employees based on Mangkunegara theoretical framework are first, ability aspect, the employees did not do the work properly, quickly and timely; besides, the employees' skills at work were not sufficiently qualified and there was no innovative action done by employees in carrying out the problems which occurred. The second is motivation aspect. In this aspect, employees did not have responsibility for their own main tasks and functions and there was no employee whose courage to take risks in completing work and also lack of enthusiasm possessed by the employees to work

The followings are some solution to improve the performance of Semarang Religious Education and Training Center employees, i.e. in work performance aspect is by adding additional employees to help old employees; from expertise aspect is by holding routine training programs to improve the employees' knowledge; while in behavior aspect is by applying strict sanctions; for ability aspect is by holding a management training program so 
that the employees can focus more at work, holding a training program to improve the employees' soft skills and a training program to improve problem solving for work problems. In addition, for motivation aspect, it is necessary to hold training to improve employees' motivation; the employees' work volume must be equally distributed based on their abilities, to hold a team building program every month and there must be a motivation training program to increase employees' motivation at work.

Based on the conclusion, the recommendations regarding this study are: It is necessary to hold a coaching clinic on time management so that the employees can manage their time at work. Consequently, they can complete their duties on time. It is necessary to conduct employees' rotation regularly by always paying attention to their educational background, employees' expertise, and types of work. Moreover, the leader or the head of the organization or institution must frequently provide more direction and motivation so that the communication process can be more open. This will lead to the employees are able to become more solid and integrated at work

Applying strict sanctions in the form of employees not being assigned for additional tasks in order to create a deterrent effect on employees. Consequently, the employees will not repeat this undisciplined actions and to be more responsible for their work

Increasing the employees' ability conducting well-programmed training to improve employees' soft skills based on their work fields

Holding self-motivation training program gradually to improve the employees' motivation in addition to the provision of additional income or bonus which should be given on time.

\section{References}

Anwar Prabu Mangkunegara. 2015. Sumber Daya Manusia Perusahaan. Cetakan kedua belas. Remaja Rosdakarya:Bandung

Bangun, Wilson, 2012, Manajemen Sumber Daya Manusia, Erlangga, Jakarta Harlie, M, 2012 , Pengaruh Disiplin Kerja, Motivasi dan Pengembangan Karier terhadap Kinerja Pegawai Negeri Sipil pada Pemerintah Kabupaten Tabalong di Tanjung Kalimantan Selatan, Jurnal Aplikasi Manajemen, STIA Tabalong Kalimantan Selatan. 
Mahmudi, (2013), Manajemen Kinerja Sektor Publik. Sekolah Tinggi.Ilmu Manajemen YKPN, Yogyakarta.

Mangkunegara., A.A. (2001). Manajemen Sumber Daaya Manusia Alih Bahasa. Jakarta: Salemba Empat

Mardiasmo. 2011. “Perpajakan Edisi Revisi”. Yogyakarta: Andi.

Purwanto. 2011. Evaluasi Hasil Belajar. Yogyakarta: Pustaka Pelajar

Sedarmayanti, 2010, Manajemen Sumber Daya Manusia: Reformasi Birokrasi dan Manajemen Pegawai Negeri Sipil, Refika Aditama, Jakarta

Sugiyono. 2013. Metode Penelitian Pendidikan Pendekatan Kuantitatif, Kualitatif, dan R\&D. Bandung: Alfabeta.

Sunarto, 2012, Metodologi, Unnes Press, Semarang.

Syaidam, Gauzali, 2015. Manajemen Sumber Daya Manusia, Suatu Pendekatan Mikro, Jakarta

Wijono, S. 2010. Psikologi Indistri dan Organisasi Dalam Suatu Bidang Gerak Psikologi Sumber Daya Manusia. Jakarta:Prenada Media Group 